10IKC-52

\title{
PHYSICAL AND INFRARED CHARACTERISTICS OF DIAMONDS FROM BEHRADIH KIMBERLITE, BASTAR CRATON, INDIA
}

\author{
Mainkar* ${ }^{*}{ }^{1}$, Gupta $\mathrm{T}^{\mathbf{2}}$, Patel $\mathrm{SC}^{\mathbf{2}}$, Lehmann $\mathrm{B}^{\mathbf{3}}$, Diwan $\mathrm{P}^{\mathbf{4}}$, Kaminsky $\mathrm{FV}^{\mathbf{5}}$, Khachatryan GK ${ }^{\mathbf{5}}$ \\ ${ }^{1}$ Directorate of Geology and Mining, Sonakhan Bhavan, Ring Road 1, Raipur 492006 India \\ ${ }^{2}$ Department of Earth Sciences, Indian Institute of Technology, Powai, Mumbai 400076 India \\ ${ }^{3}$ Mineral Resources, Technical University of Clausthal, 38678 Clausthal Zellerfeld, Germany \\ ${ }^{4}$ Department of Applied Geology, National Institute of Technology, Raipur 492010 India \\ ${ }^{5}$ KM Diamond Exploration Ltd., 815 Evelyn Drive, West Vancouver, British Columbia V7T 1J1, Canada \\ *Email:dmainkar@gmail.com
}

\section{Introduction}

Peninsular India is known for several occurrences of diamonds hosted by kimberlites and lamproites in three cratonic blocks, viz. Bastar Craton, Bundelkhand Craton and Dharwar Craton (Fig. 1). In the Bastar Craton, eluvial diamonds were first reported in the early 1990s from around Payalikhand in the state of Chhattisgarh. Investigations in the last two decades by the Geological Survey of India and the Directorate of Geology and Mining, Chhattisgarh (DGM), have led to the discovery of several kimberlites in the Bastar Craton. These kimberlites are distributed in two fields, viz. Mainpur Kimberlite Field (MKF) and Tokapal Kimberlite Field (TKF). The MKF has six intrusions, out of which four have been found to be diamondiferous. The TKF contains two intrusions, both of which are barren. Lamproite occurrences in the Bastar Craton are known from Nuapada in Odisha and Khadka in Chhattisgarh. The kimberlite and lamproite fields of the Bastar Craton are broadly aligned in a NNE-SSW trend and occur in the eastern part of the craton, close to its margin with the Proterozoic Eastern Ghats Mobile Belt.

Natural diamonds most commonly contain nitrogen as a substitutional impurity, with material categorised by the dominant form of N-bearing defect in the lattice. One of the most effective and widely used methods of investigation of structurally bound nitrogen aggregation state in diamonds is Fourier-transform infrared spectroscopy (FTIR). Infrared characteristics of Indian diamonds are poorly known. Jha et al. (1995) studied infrared characteristics 10 macrodiamonds from two intrusions in the MKF, namely Payalikhand and Behradih, and found that the diamonds have IaA-IaB spectral characteristics with low $\mathrm{N}$-aggregation. However, since the number of diamonds studied by Jha et al. (1995) was small, there is scope of refinement of their conclusions. The present work was undertaken to retrieve a sizable number of both micro- and macro-diamonds from drill core samples of the Behradih kimberlite and characterise them on the basis of their morphological and infrared characteristics.

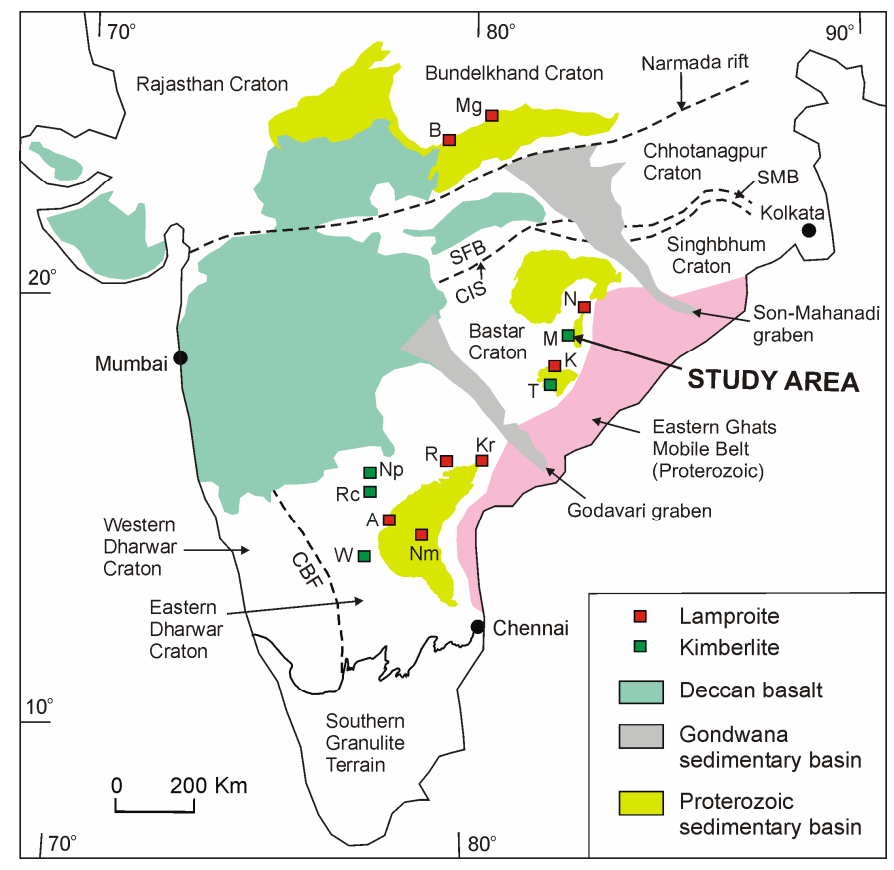

Fig.1. Schematic geological map of India showing occurrences of kimberlites and lamproites. CBF - Chitradurga Boundary Fault; CIS - Central India Shear Zone; SFB - Satpura Fold Belt; SMB Singhbhum Mobile Belt; A - Aliabad; B - Bunder; K - Khadka; Kr - Krishna; M - Mainpur; Mg - Majhgawan; N - Nuapada; Nm nallamalai; Np - Narayanpet; R - Ramadugu; Rc - Raichur; T Tokapal; W - Wajrakarur. 


\section{$10^{\text {th }}$ International Kimberlite Conference-2012}

\section{Behradih kimberlite}

The six kimberlite intrusions of the MKF are distributed in two clusters, namely Behradih cluster with Bajaghati, Behradih, Kodomali and Kosambura kimberlites, and Payalikhand cluster with Jangra and Payalikhand kimberlites (Fig. 2). The two clusters are located in a WNW-trending, $15 \mathrm{~km}$ long corridor within the Archaean Bundeli granitoid. The Payalikhand cluster occurs close to the western margin of the Khariar basin in the southeastern part of the MKF. The Khariar basin is a N-S trending Neoproterozoic platformal basin with surface dimension of $\sim 80 \mathrm{~km} \times 30 \mathrm{~km}$. Sedimentary rocks of the basin that are exposed close to the MKF include sandstone (Devdahra Sandstone) and shale (Kulharighat Formation) of the Pairi Group.

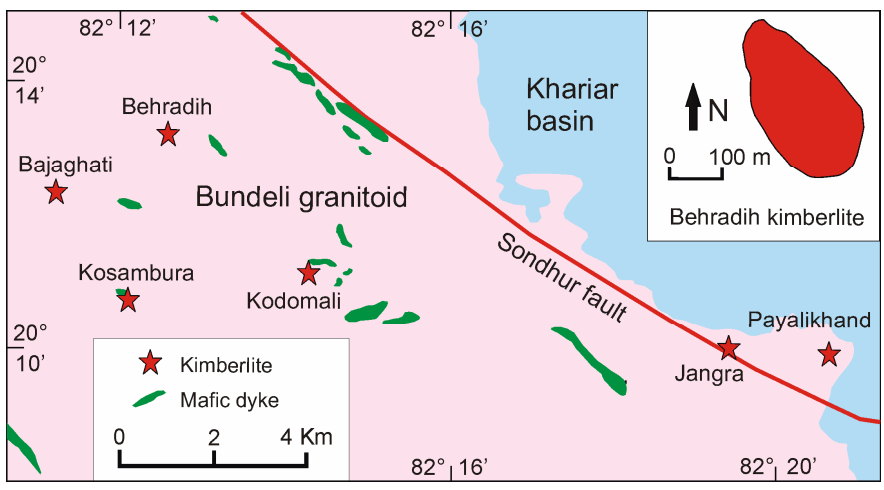

Fig.2. Generalised geological map of Mainpur Kimberlite Field. Inset shows surface outline of Behradih kimberlite.

The Behradih kimberlite $\left(82^{\circ} 12^{\prime} 06^{\prime \prime}: 20^{\circ} 12^{\prime} 54^{\prime \prime}\right)$ is a diatreme facies intrusion with surface dimension of $\sim 300 \mathrm{~m} \times$ $160 \mathrm{~m}$, and is the largest among all kimberlites in the MKF. The intrusion is covered by a thick blanket of completely weathered rock and has been explored by the DGM by drilling four angular and one vertical drill holes down to a depth of $200 \mathrm{~m}$ depth. The drill data indicate a reserve of $\sim 6.7 \mathrm{mt}$ of kimberlitic material up to a depth of $100 \mathrm{~m}$.

Petrographic study of the Behradih kimberlite shows that the rock has a macrocrystal and magmaclastic texture. The kimberlite consists of macrocrysts and microphenocrysts of olivine and phlogopite, pelletal lapilli, and autolith, all set in a groundmass of serpentine, diopside, calcite, spinel, perovskite and apatite. Geochemical and $\mathrm{Sr}$ and $\mathrm{Nd}$ isotopic data indicate that the kimberlite has affinity towards South African GroupII kimberlite (orangeite) (Chalapathi Rao et al., 2011). Lehmann et al. (2010) dated the Behradih and Kodomali kimberlites as $65 \mathrm{My}$ old. This is different from most other kimberlites in India which were emplaced $1100 \mathrm{Ma}$.

\section{Behradih diamonds}

The MKF was explored by M/s B. Vijay Kumar Chhattisgarh Exploration, Raipur, in technical collaboration with M/s Oropa Ltd. (now M/s Sihayo Gold Ltd.) until the year 2000. During prospecting, the Behradih kimberlite yielded abundant microdiamonds (<0.5 mm size) as well as macrodiamonds (> $0.5 \mathrm{~mm}$ size). Total 9 bulk samples with a combined weight of $\sim 318 \mathrm{~kg}$ yielded 391 microdiamonds (262 of $-0.1 \mathrm{~mm}, 141$ of $-0.15 \mathrm{~mm}, 55$ of $-0.21 \mathrm{~mm}, 28$ of $-0.3 \mathrm{~mm}, 5$ of $-0.43 \mathrm{~mm}$ size), and 6 macrodiamonds ( 3 of $-0.6 \mathrm{~mm}, 2$ of $-0.85 \mathrm{~mm}, 1$ of $-1.18 \mathrm{~mm}$ size) (Oropa, 2000). The DGM recovered 4 macrodiamonds with a total weight of 0.459 ct from 2.7 tonnes of pit material from the Behradih kimberlite (Verma and Saxena, 1997) which translates to a grade of $17 \mathrm{cpht}$.

For the present study, $-5 \mathrm{~mm}$ fractions of drill core material weighing a total of $\sim 125 \mathrm{~kg}$ was processed by caustic soda dissolution (CSD) and another $\sim 300 \mathrm{~kg}$ by dense media separator (DMS) for diamond incidence. The CSD yielded 86 microdiamonds of $<0.6 \mathrm{~mm}$ size, whereas the DMS yielded 35 macrodiamonds with sizes in the range of $0.6-2.2 \mathrm{~mm}$ and total weight of $0.29 \mathrm{ct}$. This translates to a diamond incidence of $\sim 90 \mathrm{cpht}$. The physical and infrared characteristics of these micro- and macrodiamonds are outlined below.

\section{Microdiamonds}

The microdiamonds are mostly colourless. Octahedral morphology (Fig. 3) accounts for nearly $70 \%$ of the population. Other forms include dodecahedron $(\sim 10 \%)$ and combination of dodecahedron and octahedron $(\sim 5 \%)$, the rest being irregular or broken fragments. The faces of octahedral crystals range from flat (Fig. 3A) to stepwise (Fig. 3B). Intergrowth of octahedra (Fig. 3C) with stacked lamellae is not uncommon. Octahedral crystals are sometimes distorted along the L4 axis (both flattened and elongated) and frequently show polycentric growth. A large proportion of octahedral crystals are resorbed to different degrees. The initial stage of resorption is expressed in trigonal etch pits, usually negatively oriented. Further resorption process has resulted in rounding of edges and apices that have lead to the formation of combined octahedral-dodecahedral crystals with shear-like striations (Fig. 3D). Some of microdiamonds bear protomagmatic spallation surfaces.

\section{Macrodiamonds}

The majority of Behradih macrodiamonds are clear, colourless and inclusion-free crystals, while a small population consists of brown and white crystals (Fig. 4). The studied crystals are mostly broken fragments, but several grains exhibit identifiable rhombical dodecahedral faces, while a few grains show octahedral faces.

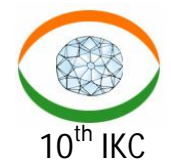




\section{$10^{\text {th }}$ International Kimberlite Conference-2012}
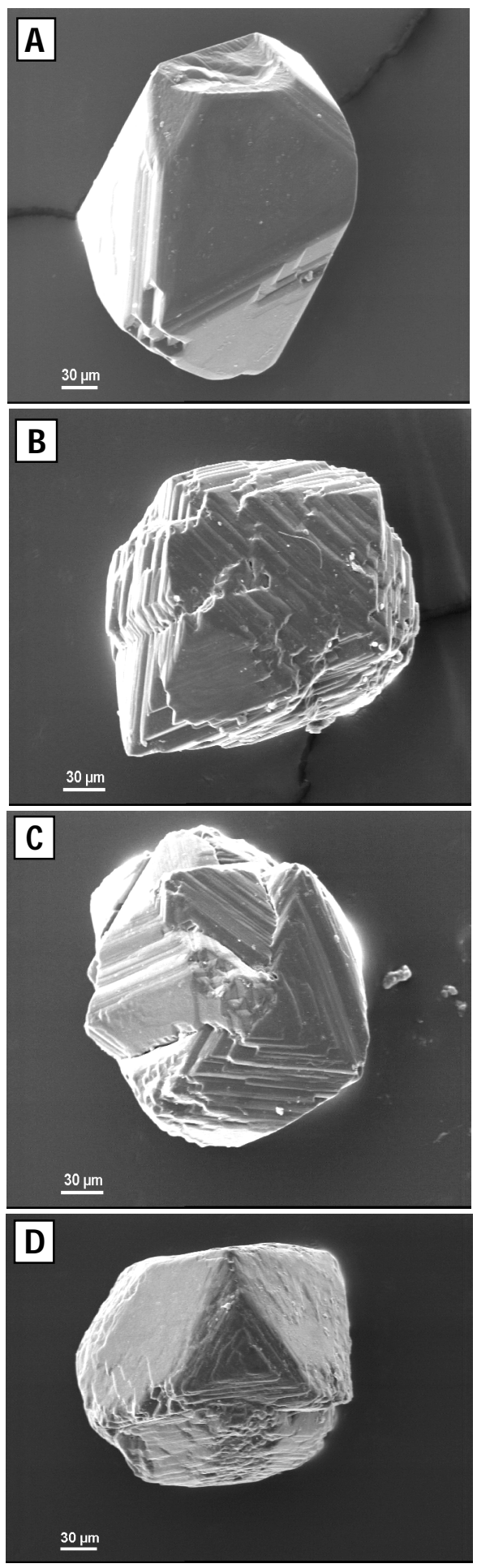

Fig.3. SEM images of Behradih microdiamonds. Length of bar scale is 30 micron. See text for description.

A few macles occur in the sample set and rarely contain negatively oriented etch marks. One of the macrodiamonds (an irregular form) shows dissolution pits shaped like negative quadrangular pyramids. Black inclusions, probably graphite, are noticed in a few crystals.

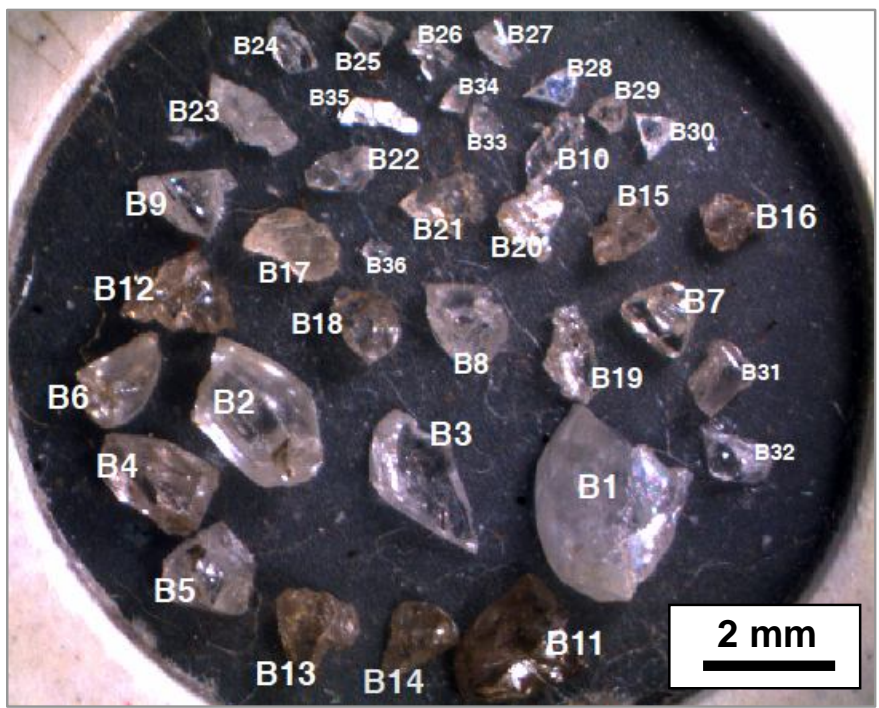

Fig. 4. Photograph of macrodiamonds from the Behradih kimberlite.

Jha et al. (1995) studied the physical characteristics of MKF macrodiamonds with 11 grains from the Payalikhand kimberlite and 7 grains from the Behradih kimberlite. They observed that all the diamonds are brown coloured with rounded dodecahedral form, except for one partially resorbed octahedron. However, our study shows that the Behradih macrodiamond population is dominated by clear, colourless and inclusion-free crystals.

\section{Infrared characteristics}

Sixteen macrodiamonds from the Behradh kimberlite were analysed by FTIR for structurally bound nitrogen aggregation state. Thirty three absorption spectra were obtained using a Brucker Vertex 80 Infrared spectrometer (fitted with Hyperion 3000 microscope) at the Indian Institute of Technology, Bombay. The spectral resolution was $4 \mathrm{~cm}^{-1}$ and recording was done by averaging the signals of 100 scans. The number of spectra per sample was in the range of 1-3 (Table 1). Concentrations of $\mathrm{N}_{\mathrm{A}}$ and $\mathrm{N}_{\mathrm{B}}$ nitrogen impurities were determined from the absorption coefficients measured for the corresponding bands in IR spectra using the following equations:

$\mathrm{N}_{\mathrm{A}}=\mathrm{K}_{\mathrm{A}} * \mu_{1282(\mathrm{~A})} ; \mathrm{N}_{\mathrm{B}}=\mathrm{K}_{\mathrm{B}} * \mu_{1282(\mathrm{~B})}=\mathrm{K}_{\mathrm{B}}{ }^{*} * \mu_{1175(\mathrm{~B})} ;$

where, $\mathrm{N}_{\mathrm{A}}$ and $\mathrm{N}_{\mathrm{B}}$ are the concentrations of A- and B-centres in at.ppm, respectively;

\section{Extended Abstract}

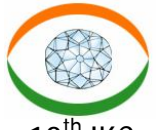




\section{$10^{\text {th }}$ International Kimberlite Conference-2012}

Table 1. Results of IR spectral decomposition. Sample numbers correspond to those in Fig. 4.

\begin{tabular}{lllllllll}
\hline $\begin{array}{l}\text { Sample } \\
\text { no. }\end{array}$ & Shape & Color & $\begin{array}{l}\text { No. of } \\
\text { spectra }\end{array}$ & $\mathrm{N}_{\mathrm{A}}, \mathrm{ppm}$ & $\mathrm{N}_{\mathrm{B}}, \mathrm{ppm}$ & $\mathrm{N}_{\text {tot }}, \mathrm{ppm}$ & $\% \mathrm{~N}_{\mathrm{B}}$ & $\mathrm{P} \mathrm{cm}^{-1}$ \\
\hline B-1 & D-F & CL & 3 & 471 & 228 & 699 & 37 & 11.8 \\
B-2 & D-F & CL & 3 & 573 & 313 & 886 & 35 & 8.0 \\
B-3 & D-F & CL & 2 & 640 & 310 & 950 & 33 & 10.1 \\
B-4 & I & CL & 2 & 312 & 118 & 430 & 27 & 7.2 \\
B-5 & O-F & CL & 2 & 511 & 417 & 929 & 45 & 10.7 \\
B-6 & D-F & CL & 2 & 431 & 292 & 725 & 40 & 9.1 \\
B-7 & M & CL & 2 & 362 & 409 & 771 & 53 & 28.3 \\
B-8 & Fr & CL & 2 & 523 & 253 & 776 & 33 & 14.2 \\
B-9 & M & CL & 2 & 456 & 270 & 726 & 37 & 15.1 \\
B-11 & I & BR & 2 & 347 & 130 & 477 & 27 & 8.8 \\
B-12 & Fr & BR & 2 & 307 & 145 & 457 & 32 & 9.0 \\
B-13 & Fr & BR & 3 & 343 & 96 & 439 & 22 & 8.8 \\
B-14 & I & BR & 1 & 279 & 79 & 358 & 22 & 8.3 \\
B-15 & Fr & BR & 1 & 282 & 246 & 528 & 47 & 15.1 \\
B-18 & I & CL & 2 & 550 & 341 & 891 & 38 & 18.3 \\
B-23 & Fr & W & 2 & 415 & 241 & 656 & 37 & 13.9 \\
\hline
\end{tabular}

Note: $\mathrm{D}$ - rhombical dodecahedron, $\mathrm{O}$ - octahedron, $\mathrm{M}$ - macle, $\mathrm{F}$ - fragment, $\mathrm{Fr}$ - fraction, I - irregular, $\mathrm{CL}$ colourless, BR - light brown to brown, W - Frosted white.

$\mathrm{K}_{\mathrm{A}}=16.5 \pm 1$ at.ppm (Boyd et al., 1994), $\mathrm{K}_{\mathrm{B}}=79.4 \pm 8$ at.ppm (Boyd et al., 1995) and $\mathrm{K}_{\mathrm{B}}{ }^{\prime}=26.6$ at.ppm (Khachatryan, 2003) are the coefficients for A- and B-centres, respectively; $\mu_{1282}$ and $\mu_{1175}$ are the values of absorption peaks at frequencies of $1282 \mathrm{~cm}^{-1}$ and $1175 \mathrm{~cm}^{-1}$, respectively; $\mu_{1282(\mathrm{~A})}$ and $\mu_{1282(\mathrm{~B})}$ for $\mathrm{A}$ - and B-centres in each analysis were calculated according to Bokii et al. (1986). The results of these calculations are in full agreement with the results calculated with the use of the method by Mendelssohn and Milledge (1995).

All the Behradih macrodiamonds belong to the IaAB diamond type with a predominance of A-centre (a pair of nitrogen atoms jointly replacing a single carbon atom) over Bcentre (an aggregate of nitrogen atoms tetrahedrally arranged around a vacancy). The total nitrogen content $\left(\mathrm{N}_{\text {total }}\right)$ of the diamonds falls in the range of 358-950 at.ppm, based on which they are classified as Group 2 of medium-nitrogen diamond to which the majority of natural diamonds belong, or more precisely to Group 2a with a relatively higher nitrogen content, 400-1000 at.ppm (Kaminsky and Khachatryan, 2001) (Fig. 5). The proportion of aggregated nitrogen $\left[\% \mathrm{~N}_{\mathrm{B}}=\right.$ $\left.100 \mathrm{~N}_{\mathrm{B}} /\left(\mathrm{N}_{\mathrm{A}}+\mathrm{N}_{\mathrm{B}}\right)\right]$ in the diamonds varies from 22 to $45 \%$, based on which the Behradih diamonds belong to Groups 2 ('intermediate') and 3 ('low-aggregated diamond') of Kaminsky and Khachatryan (2001) (Fig. 6). This parameter, which depends on the mantle residence temperature and age of diamond (Evans, 1992), indicates that the Behradih diamonds formed at c. $1100-1125^{\circ} \mathrm{C}$, assuming a diamond age of c. 3
$\mathrm{Ga}$, like for the most of peridotitic diamonds in different parts of the world. However, this estimate needs to be corrected when the real age of diamonds from the Bastar Craton is known.

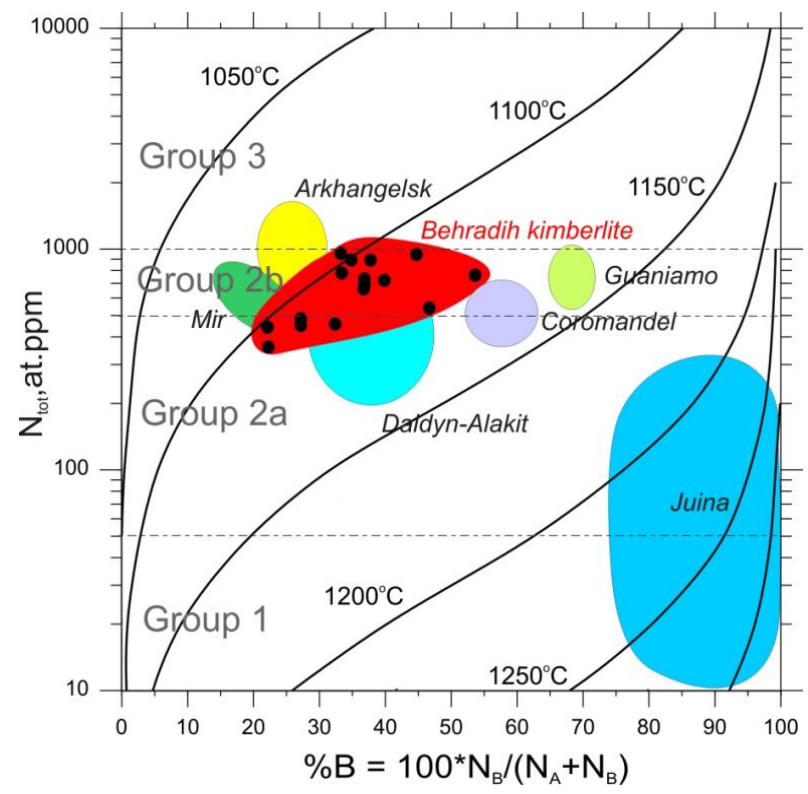

Fig.5. Temperature estimates for diamonds from different areas (after Kaminsky and Khachatryan, 2001). Isotherm curves for $3 \mathrm{Ga}$ after Taylor and Milledge (1995). 


\section{$10^{\text {th }}$ International Kimberlite Conference-2012}

It is notable that our calculated range of $\% \mathrm{~N}_{\mathrm{B}}$ and estimated range of mantle residence temperature for the Behradih diamonds are significantly higher than those of Jha et al. (1995), who reported 5-23\% $\mathrm{N}_{\mathrm{B}}$ and an average mantle residence temperature of $\sim 1080^{\circ} \mathrm{C}$ for both Behradih and Payalikhand diamonds.

In terms of $\mathrm{N}_{\text {total }}$ and $\% \mathrm{~N}_{\mathrm{B}}$, the Behradih diamonds are similar to those from major primary diamond deposits in Siberia (Mir, Daldyn-Alakit area) and Archangelsk. Diamonds from the Urals and the Slave Craton, Canada belong to the same group, while diamonds from placer deposits in Venezuela (Guaniamo area) and Brazil (Coromandel, and particularly Juina area) have more aggregated nitrogen. According to the classification of Khachatryan (2010) for diamonds from primary and placer deposits in Siberia, these are Type IV diamonds, very characteristic for the Mir pipe and placer deposits in the Urals. Such diamonds, most frequently, have layer-by-layer octahedral or sectorial-zonal internal structure and may contain both peridotitic-type and eclogitictype mineral inclusions.

Concentration of 'platelet' (linear defects several atoms thick; Woods 1986) in the diamonds was calculated in arbitrary units $\left(\mathrm{cm}^{-1}\right)$ as a function of the absorption coefficient value measured at $1365 \mathrm{~cm}^{-1}$. These values are within the range of $8.0-28.3 \mathrm{~cm}^{-1}$ (Table 1). By this parameter, the Behradih diamonds are close to the ones from the Arkhangelsk and Daldyn-Alakit deposits as well as from the Urals and Slave Province, Canada.

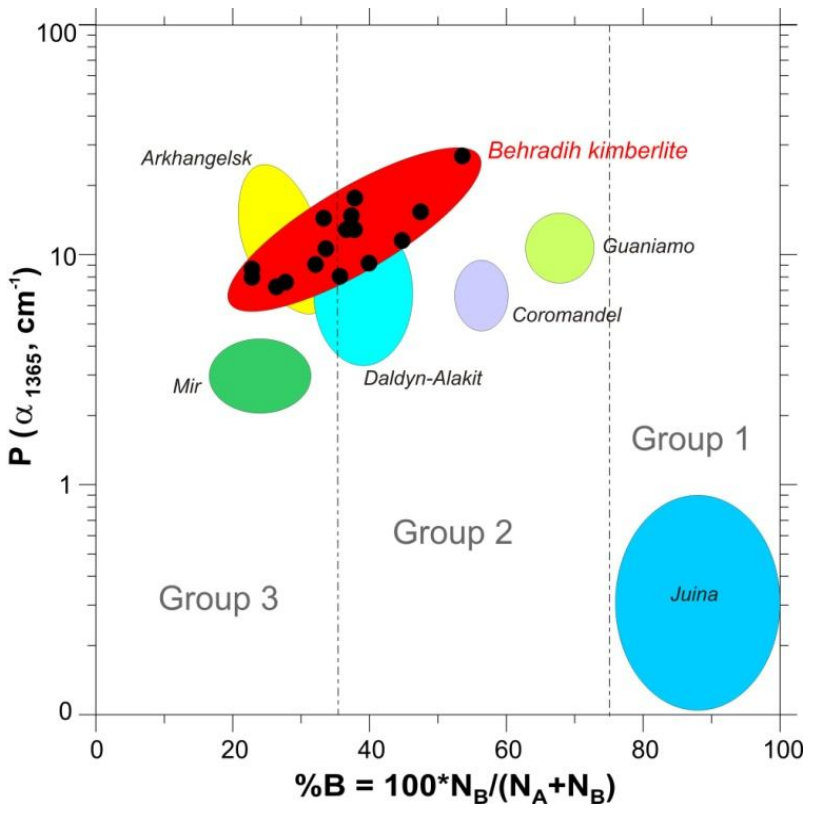

Fig.6. Distribution of 'platelets' $(\mathrm{P})$ and aggregated nitrogen proportion $\left[\% \mathrm{~N}_{B}=100 * \mathrm{~N}_{\mathrm{B}} /\left(\mathrm{N}_{\mathrm{A}}+\mathrm{N}_{\mathrm{B}}\right)\right.$ ] in diamond from different regions (after Kaminsky and Khachatryan, 2001). P is an average 'platelet' content in diamond in arbitrary units as a function of the absorption coefficient value measured at $1365 \mathrm{~cm}^{-1}$.

\section{References}

Bokii, G.B., Bezrukov, G.N., Klyuev, Yu.A., Naletov, A.M., Nepsha, V.I. (1986) Natural and synthetic diamonds. Nauka Press, Moscow (in Russian).

Boyd, S. R., Kiflawi, I. and Woods, G. S. (1994) The relationship between infrared absorption and A-defect concentration in diamond. Phil. Mag., v.B69, pp. 1149-1153.

Boyd, S. R., Kiflawi, I. and Woods, G. S. (1995) Infrared absorption by the B nitrogen aggregate in diamond. Phil. Mag., v.B72, pp.351-361.

Chalapathi Rao, N.V., Lehmann, B., Mainkar, D. and Belyatsky, B. (2011) Petrogenesis of the end-Cretaceous diamondiferous Behradih orangeite pipe: implication for mantle plumelithosphere interaction in the Bastar craton, Central India. Contrib. Mineral. Petrol., v.161, pp.721-742.

Evans, T. (1992) Aggregation of nitrogen in diamond. In: The properties of natural and synthetic Diamond (J. Field, ed). Academic Press, London, pp.259-290.

Jha, N., Smith, C.B., Griffin, B.J., Chatterjee, B. and Pooley, G.D. (1995) Diamonds from the kimberlites of southeastern Raipur Kimberlite Field, Raipur district, Madhya Pradesh, central India. In: Sixth Internat. Kimberlite Conf. Extended Abstr., Novosibirsk, August 1995, pp.266-268.

Kaminsky, F.V. and Khachatryan, G.K. (2001) Characteristics of nitrogen and other impurities in diamond, as revealed by infrared absorption data: Can. Mineralogist, v.39, pp.1733-1745.

Khachatryan, G.K. (2003) Improved methods of evaluating of nitrogen concentration in diamond and their practical application. Geological Material Base ALROSA, Mirny, pp.319-321(in Russian).

Khachatryan, G.K. (2010) Classification of diamonds from kimberlites and lamproites according to distribution of nitrogen centers in crystals. Rudi i Metalli (Ores and Metals), No.2, pp.46-60 (in Russian).

Lehmann, B., Burgess, R., Frei, D., Belyatsky, B., Mainkar, D., Chalapathi Rao, N.V., Heaman, L.M. (2010) Diamondiferous kimberlites in central India synchronous with Deccan flood basalts. Earth Planet. Sci. Lett., v.290, pp.142-149.

Mendelssohn, M.J. and Milledge, H.J. (1995) Geologically significant information from routine analysis of the mid-infrared spectra of diamonds. International Geol. Review, v.37, pp.95110.

Oropa (2000) Office announcement on Raipur diamond project, Block D-7, Madhya Pradesh, India, November 23, 2000, www.sihayogold.com.

Taylor, W.R. and Milledge H.J. (1995) Nitrogen aggregation character, thermal history and stable isotope composition of some xenolith-derived diamonds from Roberts Victor and Finch. In: Sixth Internat. Kimberlite Conf. Extended Abstr., Novosibirsk, 1995, 620-622.

Verma, D. and Saxena, V.K. (1997) A report on investigation for diamond and other precious-semiprecious stones in southeastern parts of district Raipur, M.P., F.S. 1992-94, Unpub. Report of DGM, M.P.

Woods, G.S. (1986) "Platelets" and the infrared absorption of type Ia diamonds. Proceedings of the Royal Society, London, A407, 219-238. 